Still Broken 



\section{Still Broken}

Understanding the U.S. Health Care System

STEPHEN M. DAVIDSON

Stanford Business Books An Imprint of Stanford University Press Stanford, California 
Stanford University Press

Stanford, California

(C)20Io by the Board of Trustees of the Leland Stanford Junior University. All rights reserved.

No part of this book may be reproduced or transmitted in any form or by any means, electronic or mechanical, including photocopying and recording, or in any information storage or retrieval system without the prior written permission of Stanford University Press.

Special discounts for bulk quantities of Stanford Business Books are available to corporations, professional associations, and other organizations. For details and discount information, contact the special sales department of Stanford University Press. Tel: (650) 736-I782, Fax: (650) 736-I784

Printed in the United States of America on acid-free, archival-quality paper

Library of Congress Cataloging-in-Publication Data

Davidson, Stephen M.

Still broken : understanding the U.S. health care system / Stephen M.

Davidson.

p. $\mathrm{cm}$.

Includes bibliographical references and index.

ISBN 978-0-8047-6I96-3 (cloth : alk. paper)

I. Health care reform-United States. 2. Medical policy-United

States. I. Title. [DNLM: I. Health Care Reform-United States.

2. Health Expenditures-United States. 3. Health Services

Accessibility-economics-United States. 4. Health Services Needs and Demand-economics-United States. 5. Quality Assurance, Health Care-economics-United States. WA 540 AAi D253s 20Io]

RA 395.A 3 D 3852010

362.I'0425一 dc22

2009049992

Typeset by Classic Typography in I0.5/12 Bembo 
To the memory of Nachman Davidson and Odin W. Anderson, the two men who introduced me to the mysteries of the health care system and For Noah, Aaron, Tess, Hannah, and Eli, in the hope that the health care system of the future will serve them well 

Some look at things that are and ask, Why?

I dream of things that never were, and ask why not? - George Bernard Shaw, quoted by Robert F. Kennedy

I still have faith in the American people to do the right thing.

- Theodore Sorensen

Counselor: A Life at the Edge of History 
